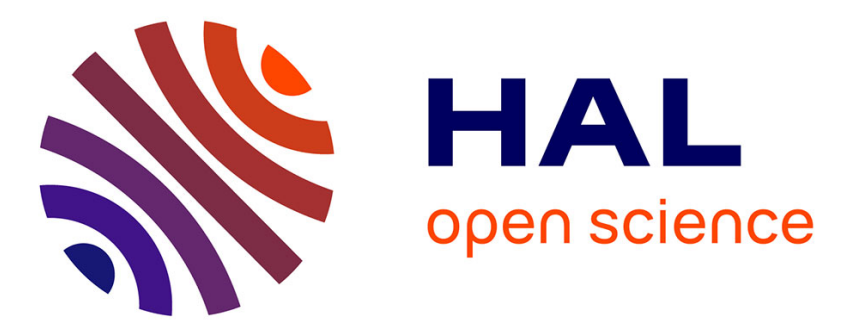

\title{
Knowledge that is actionable by whom? Underlying models of organized action for conservation
}

\author{
Laurent Mermet
}

\section{To cite this version:}

Laurent Mermet. Knowledge that is actionable by whom? Underlying models of organized action for conservation. Environmental Science \& Policy, 2018, 10.1016/j.envsci.2018.04.004 . hal-02910293

\section{HAL Id: hal-02910293}

\section{https://hal-agroparistech.archives-ouvertes.fr/hal-02910293}

Submitted on 1 Aug 2020

HAL is a multi-disciplinary open access archive for the deposit and dissemination of scientific research documents, whether they are published or not. The documents may come from teaching and research institutions in France or abroad, or from public or private research centers.
L'archive ouverte pluridisciplinaire HAL, est destinée au dépôt et à la diffusion de documents scientifiques de niveau recherche, publiés ou non, émanant des établissements d'enseignement et de recherche français ou étrangers, des laboratoires publics ou privés. 
Knowledge that is actionable by whom? Underlying models of organized action for conservation. Laurent Mermet

\section{Introduction}

Many ecologists and conservation biologists feel a need for their research to make a difference in the face of the biodiversity crisis. As this need has been taken up by the field's literature and professional societies, the prevalence of a "knowing-doing gap" (Knight et al., 2008) has emerged as a salient point of such reflection. More recently, the focus is moving towards responsibility of the researchers themselves. Attention is then drawn to the connexions that scientists should reinforce or create with actors in the practical world, whether these are defined as decision-makers, practitioners, stakeholders, or local people (Cook et al., 2012; Toomey et al., 2016). Many authors also point to the content of research, and to the responsibility of scientists to produce research that is relevant for action. Margaret Palmer describes such research as actionable "because it has the potential to inform decisions (in government, business, and the household), to improve the design of implementation of public policies, or to influence public- or private- sector strategies, planning and behaviours that affect the environment." (Palmer, 2012, p.5).

But by whom exactly should such research be actionable? And with whom should scientists engage in "research-implementation spaces", as Toomey et al. (2016) encourage them to do? Doing our own work in management, a discipline that puts much emphasis on who exactly is supposed to do what for goals to be met, on who actually does what and on who is accountable to whom in the process, we find ourselves regularly puzzled as we read and listen to conservation scientists discussing their connexions with the world of conservation action. We are quite attentive to whom they see as taking up science (or participating in it) and acting on research findings and we often find their answers to be more or less incomplete. As we shall elaborate, sometimes the answer is vague (e.g. "humanity must act now to curb the loss of tropical forests", or "it is essential to improve governance of biodiversity conservation mechanisms on the ground"), sometimes it is glossed over e.g. by using the passive form ("the regulations will have to be changed"), or it points to only some actors ("ecosystem management agencies", or "local people must be involved alongside with protected-area managers") and is not structured (as in Palmer's citation above, which offers a rather comprehensive enumeration, but doesn't locate potential interlocutors in an organized scheme or a pattern that helps hierarchize between them).

This hitch with the identification of immersed-in-action-partners points to the wider issue of organized action. If relevant science is going to make a difference through action, that action will 
surely be collective action of one sort or another. It could be much enhanced, and the debate enriched, by a wider and clearer general view of the issues of agency (who is supposed to take action?) and of organized action (what are the structural links and power dynamics between the main actors) that underlie conservation action in general, and the way it uses science in particular.

We propose here an explanation and analysis of the alternative conceptual models of collective action that inform thought and practice in the field of action on conservation issues. We have come to this choice and explanation of conceptual models gradually through years of research on decision-making processes on environmental issues (Mermet and Leménager, 2015), on conservation and the use of various policy tools (Mermet et al., 2014), on environmental policy evaluation (Mermet et al., 2010). Admittedly this explanation of underlying models is a work in progress and the reader will find their presentation here more complete (more models considered) and with further conceptualization than in previous tentative expositions (Mermet et al., 2013).

We shall start by a critique of one often encountered but highly anti-pragmatic implicit model of action, i.e. that we are all responsible for biodiversity and affected by it, and thus, should act all together. As we cannot literally act all together, but only some of us can or want to act on collective problems even if they are shared by all, we then turn to a systematic review of the main possible answers to the question: "who is to act on our collective problems, and what is the main thrust of such action?" We will review six underlying conceptual models of organized action, each of which offers a distinctive answer to this question. Each of them outlines a very different context for the place and role of research in conservation action. Each of them frames quite differently the meaning and value of conservation research. Each of them suggests different (and not always compatible) avenues for improving how conservation scientists connect with conservation actors and action. In the final discussion we shall return to the current state of the debate on bridging research and action in biodiversity conservation, hoping to show that the proposed clarification enhances existing contributions and actively invites and contributes to new ones.

2. Dispelling the hathroologic illusion and spelling out explicit models of agency and organized action

In 2002 at the Rio +10 conference in Johannesburg, French president Jacques Chirac opened his speech with a sentence that struck a chord: "our house is on fire, but we are looking the other way". This expresses the most basic model of collective action on environmental problems: we are one humanity, we have one problem (climate change, biodiversity crisis, etc.) so we must act as one, exactly as would do one person or one family that discovers that their house is on fire. Fifteen 
years later, as philosopher Clive Hamilton denounces "the great climate silence" and warns that "we are on the edge of the abyss but we ignore it" (Hamilton, 2017), he expresses exactly the same underlying model of collective action. It is, again, the same model that the "knowing but not doing" phrase expresses in the conservation debate. We propose to name that model "hathroologic", based on greek hathroos that qualifies large groups (e.g. the people of a city) acting en masse, as one. It is important to name that model because we find it to be widespread in biodiversity conservation (and more generally, environmental) debates. It needs to be explained and criticized because it sounds grand, but obfuscates crucial issues of agency.

Let us use the "climate silence" as an example for critical analysis of hatroology. Is everybody "silent" on climate issues? Far from it: it is abundantly discussed publicly, including by the author of the phrase (Hamilton, 2017). Does everybody ignore it? Far from it: it is a salient point on the international agenda, in all major news media and a lot of practical action is being taken by many people, at many levels. Similarly in biodiversity conservation, it would be hard to argue seriously that no meaningful action is taking place, that not many people are involved in it, or that what action is taking place makes no use of knowledge from research.

The hatroologic discourse disassembles quickly under scrutiny for two reasons. (1) It calls to action by entities (society, humanity, "us all", etc.) that exist as aggregates but have no concrete existence as actual pragmatic operators, operators that could actually act on knowledge provided by scientists; this encourages unrealistic reasoning about moving from knowledge to action. (2) It exacerbates feelings of powerlessness as what is a relative lack of power (some of us are acting a lot for conservation, but against powerful opposition and difficult odds) is turned into absolute powerlessness (compared to what would be "real" action - i.e. unanimous and completely effective - we do nothing).

Indeed, assigning action to "humanity" or "society" can be a figurative manner of speech, shorthand for complex series of actions that leads to results than can be assessed as if "humanity" or "society" as a whole had acted. And leaving open the issue of who might do the action can be a way to hand over an important agenda point or technical tool without having to presuppose who exactly is to act on it. Such moves amount to conservation scientists addressing their findings and recommendations "to whomever they may concern". This may be appropriate in a variety of contexts. In many cases however, it is neither appropriate nor useful. For instance, it is incoherent to address one's findings to "whomever" and then lament that no one seems to express concern and act on it. Also, if one is looking for relevant partners to take up knowledge about biodiversity and act on it, reasoning on the basis of "humanity should" or "one could" will provide poor guidance. 
As they participate in knowledge-to-action initiatives, conservation scientists and their social science allies have to steer away from hatroologic reasoning and passive voice statements and enter the fray where concrete actors, the structural links and power dynamics between them shape biodiversity outcomes. Many of them do that through a case by case approach by engaging specific field situations and reflecting in a practical manner on the actors that may be relevant for conservation action in that situation and on the relations between them. Others advocate more general approaches to improve the paths that lead from conservation knowledge to action, e.g. to increase stakeholder involvement in research, or include a critique of large scale power structures in the analysis of specific field situations.

A further step to sustain such efforts is to examine in a systematic manner the various possible perspectives that one can adopt to analyse the kind of operators and the kind of action that they envision as potentially leading from knowledge to action. The following set of seven questions can guide that exercise.

- Who are we expecting to act on whom in order to produce the changes we recommend? Who do we expect to lead the action?

- Who gets to define the issues and prioritize them (e.g. between conservation and other concerns)?

- Who is accountable to whom (for biodiversity, and for other issues that may be affected by conservation)?

- What is the place and role of actors who are specialized in conservation (NGOs, conservation scientists, etc.)?

- What (or who) causes the biodiversity problem that conservation action intends to address?

- What course of action could effectively address this (or these) biodiversity degradation inducing actions or processes?

- What privileged forms of action could be envisaged?

The first four are focusing on actors and organisational relations between them, the last three focus on problem identification and problem solving. Realistic action for conservation is a combination of power relations and problem solving: dealing with power relations in a way that leads to effectively halting a biodiversity degrading process.

Precise answers to such questions are highly context-specific and this set of questions can be taken as a guide to quick and dirty diagnostic of specific conservation knowledge-to-action situations. However on a more general level, the kind of answers that one tends to privilege defines a repeatable perspective and amounts to a broad underlying conceptual model of organized action. 
In the conservation literature and debate, as well as in concrete conservation initiatives, we have found six such models to be particularly salient and useful to consider. As we now set out to describe each of them in turn, let us just keep in mind that they are ways to structure reasoning about organized action for conservation, conceptual models that may underlie both the design of conservation action and its analysis in research about conservation action. For each model, we propose a new technical term, alongside with a lay phrase that may alternatively designate it. The former may seem arcane at first, but they have the advantage (1) of being more concise, (2) of building on fundamental conceptual synergies (e.g. the combination of initiative and power in the "archic" model, or of dispersion and planting seeds in the "speiric"model), (3) of preventing misunderstandings (e.g. "this is not how I see governance, or government") and (4) of associating explicitly each model with the overall framework that is proposed here.

\section{Government-as-the-operator, or the archic model}

In this model it is established public authority that is expected to act on behalf of society. Government (e.g. national or local) is seen as the main operator in charge of taking action on public problems like conservation and of prioritizing issues. Here, all stakeholders, all members of the public are accountable to government for their behaviour and it's impacts; and government is accountable in turn for its choices and for its effectiveness in solving conservation problems. In this perspective, the major path from knowledge to action, is for knowledge to inform government decision-makers at all stages of policy: agenda setting, prioritizing conservation or amongst conservation issues, policy design as it has to rest on sound knowledge, and policy evaluation. This sets roles for conservation scientists as advisers to the prince, as experts participating in public policy, as a public voice speaking directly to the authorities about what they could or should do for conservation.

We call this model archic based on greek archos, that combines the idea of the leader, the chief, the source of initiative. In archic reasoning the initiative and the power of acting for conservation both rest on the authorities. This paradigm plays a major role in conservation research, as conservation scientists strive to influence the agenda of public policy, to inspire regulation, to provide technical tools (maps, models, inventories, etc.) for the implementation of policy, and as it (often implicitly) posits conservation researchers who reflect on action in a form of advisory dialogue with the authorities.

A focus on legal official goals and legal norms, on the kind of instruments (laws, subsidies, etc.) that are governmental in nature, on the authorities as legitimate to act and having a duty to do so, on 
policy implementation, its difficulties and shortcomings, are all indicators that one is immersed in archic (government-as-operator) reasoning.

\section{Coordination-as-resolution, or the agoric model}

The agoric model assigns the responsibility for acting on the problem to the stakeholders themselves, without the involvement of authorities. It is negotiation between them that should prioritize issues, decide on what action to take, implement and evaluate such action. In this perspective, stakeholders are accountable directly to one another. In agoric reasoning the main vector of action is through approaches like mediation and other tools that enhance communication, coordination and collaboration, and focus on sitting all the actors around the proverbial table.

Elinor Ostrom's Governing the Commons (1990) is a very influential example of agoric reasoning, as it posits direct negotiation of resource-use rules between resource users themselves as the crux of managing common-pool resources. Another example is the classic definition of payments for ecosystem services (Wunder, 2005), that insists that ecosystem services users directly negotiate and effect payments to providers. It is worth underlining that from an organisational and power relations standpoint, the important trait of the agoric model is not whether one negotiates about rules, about money, about technical options or about other issues: the fundamental trait is that stakeholders negotiate directly solutions to environmental problems with one another. The greek word agora reflects that trait as it means both the assembly and the market: on the city's central square, people negotiated all their dealings, practical, political, social or commercial.

In the agoric (coordination) paradigm, conservation scientists' role can be either as support to mediation, or as support to one of the stakeholders negotiating for better biodiversity management. Forms of applied conservation research that promote direct engagement with stakeholders as they negotiate between themselves, co-production with them of knowledge and action, not involving the authorities, refer to that paradigm of collective action.

\section{Governance-process: the diagogic model}

The third model is a hybrid combination of the previous two as it sits somewhere between government and direct negotiation of solutions between stakeholders. It finds its source in two converging pressures. On the one hand, officials conducting government policies often meet difficulties in design and implementation, to the point that they endeavour to involve stakeholders at various stages of policy. On the other hand, social innovators who experiment with agoric solutions 
- i.e. direct negotiation - are often confronted with the limitations of what can be achieved without government involvement (e.g. without the support of law enforcement, or without legal changes, or without support from public funds) and so, they may seek collaboration of public authorities to bottom-up negotiated solutions. The resulting model of organized action is governance: "multi-level interactions [...] among, but not limited to, three main actors, i.e., state, market, and civil society, which interact with one another [...] in formulating and implementing policies in response to environment-related demands and inputs from the society, bound by rules, procedures, processes, and widely-accepted behavior, [...] for the purpose of attaining environmentally-sustainable development." (Floranoy, http://ecogov. blogspot.com/2007/04/ - for a discussion of issues in defining governance, see Mermet et al., 2013, p.52).

This model is identified by two main traits. (1) It insists on forms of collaboration between actors with, and without, public mandates: public participation in decision-making, public private partnership, joint committees and other forms of deliberative forums that downplay the heterogeneity in the institutional standing of members. (2) It assigns to decision-making procedures the central role in treating collective action problems. This contrasts both with archic reasoning (the central point is substantive and instrumental: a decision-maker choosing the right tool for action) and with agoric reasoning (the central point is agreement between peers, whatever the ways in which the agreement has been reached). Explicit, visible, often complex procedures reduce the tension inherent in situations where operators with a clear institutional mandate (e.g. elected officials, civil servants) collaborate with others who do not have any (e.g. NGO activists, inhabitants who have been invited to a round table or who have simply shown up at a public participation meeting). Thus the choice of the term diagogic for this model: procedure is expected to support action by leading through (diagoo) situations involving heterogeneous actors and issues.

The diagogic (governance-process) paradigm is familiar to conservation operators in many forms like action plans designed by committees and public participation events, biodiversity strategies involving government, NGOs and private firms, or community-based protected area management. For conservation scientists, this creates environments where the way from knowledge to action is through active involvement in procedures of biodiversity governance. This can take many forms, e.g. involving the public in the research itself, involving stakeholders in the research agenda, participating as experts in conservation planning procedures, etc.

\section{Revolution-required-for-change: the stasic model}


In the stasic model, the authorities - and more widely the political- economic regime - are seen not as the source of solutions, nor as part of the solution, but as the main source of the problem as they act to perpetuate dysfunctional activities and power relations that are seen as being the root cause of biodiversity loss. In this perspective, the main course of action has to be to stand up in the face of the system and overthrow the government that keeps it in place. Everyone is accountable, in a Manichean way: either they participate in the activities of the system and they are responsible for the problems, or they oppose squarely the system and they are part of the solution. Greek stasis standing up in revolt, attempts at overthrowing the government, civil war - reflects both the structure of this confrontation of powers and the spirit of standing up to the powers that be that pervades much of the environmental literature based on that model. The title of Joel Kovel's book "The Enemy of Nature- the End of Capitalism or the End of the World" (2002) summarizes in a nutshell one of the possible diagnostics of the biodiversity crisis based on that underlying model.

Who is then to act? To effect a revolution, a mobilisation of the masses is required because only they can accumulate the strength to overturn the political regime: they (and the revolutionaries who mobilise and lead them) are the decisive operators. Such mobilisation cannot rely on one very specific issue (like biodiversity). To mobilize masses, it is required to present a large set of public concerns as being jointly the consequences of the existing system, and revolution as the joint solution to that whole set of problems. The issue is then not to prioritize issues but on the contrary (in line with the Manichean structure of that model) to amalgamate on the one hand all the issues that one sees as rightful and suffering from the system (from biodiversity to poverty, from discrimination to educational problems, etc.) and on the other hand all the issues that are deemed illegitimate and part of the system (large scale logistics for food production and distribution, automobile traffic issues, etc.).

The stasic (revolution) paradigm is troubling for conservation scientists. Should they join wider oppositional mobilizations or should they participate in governments' efforts towards sustainable development? On April 29th, 2015, protesters opposing the construction of an airport at NotreDame des Landes (France) attacked scientists from an ecology lab who were doing field work because they saw their studies as a contribution to decision-making about the project and thus as part of the system that justifies and supports such ecosystem-destroying projects (Certain, 2015).

\section{Minority-actor-for-change: the zelic model}

The zelic model shares one premise with the previous one (stasic). The initiative of change cannot rest primarily on the government, nor on the circle of major existing stakeholders, since states of 
affairs detrimental to biodiversity are precisely the result of existing balances of power and interests that government (in the archic paradigm) and negotiation between major stakeholders (in the agoric paradigm) act to maintain. So the onus of acting in favour of biodiversity has to rest on those actors for whom it is a priority concern to the point that they are ready to struggle against other stakeholders and established balances of power and interest. In the zelic paradigm however, the scope, the aims and the means of this action for change differ from stasic reasoning.

In terms of scope, it rests on pluralism, i.e. on recognizing that there is a multiplicity of legitimate public concerns, and that they are not necessarily always compatible or convergent (e.g. a dam project that alleviates rural poverty in some valley can be detrimental to biodiversity). As a result, each public concern can be defended on its own grounds in the face of all the other (public or private) concerns. It also rests on the diagnostic that biodiversity issues are caused not so much by "the system" as a whole as by specific actors, techniques and projects. In this perspective, the massive impact of European agriculture on terrestrial biodiversity is the result of a finite series of inappropriate choices in terms of crops (e.g. irrigated corn), farming techniques (e.g. pesticides), location (e.g. replace high nature value agricultural systems by intensive ones), etc. And behind such choices are identifiable operators and it is them that action for change should target. The aim of action for change is thus to transform the system, so that specific biodiversity issues are better managed, not to throw down the economic and political system wholesale (as in the stasic paradigm). And the means for this are all the possible means for a struggle to increase the level of priority given to specific biodiversity issues, and to identify and overcome specific actors resisting change.

The zelic paradigm essentially attribute to minority set of actors the onus to change large systems of practice and power that negatively affect biodiversity, the main spring of action being the particularly high priority they assign to that issue (thus the choice of the word zelos, greek for passion, zeal for something, somebody, or against somebody). The idea of a minority actor reflects the feeling of an uphill battle, of strategy from the weak to the strong, that defenders of biodiversity often express. On a deeper theoretical level, it refers not to the amount of power available to such actors, but to the exact opposite of the hatroologic discourse: the fact that by opting for one cause that is just one amongst many in a deeply pluralistic world, one becomes logically a minority (Deleuze and Guattari, 1980). Rachel Carson's book "Silent spring" (1962) is an emblematic example: one singular voice confronting a host of interests that converge against biodiversity. A striking point of the model is that seen from the minority-actor's perspectives, other actors are structurally seen as having too much power. For instance as Chris Sandbrook (2017) critically examines the power positions of conservation groups, he finds them at first sight to be too weak 
when seen from their own perspective, and too strong in relation to marginalised people that may be affected by conservation - i.e. when seen from the perspective of other minority-interest actors, such as those who defend the rural poor or indigenous people. It is not a matter of uneven power, as seen from an overlooking moral standpoint, but of asymmetry of prupose and perspective.

Theory-wise, in the environmental field there are several approaches that analyse how this can result in actual change, despite apparently impossible odds. Sabbatier and Jenkins' advocacy coalition theory (1993) shows how the gradual construction of coalitions around an issue can (sometimes) result in changing the course of public policies. The concept of policy windows (Rose et al., 2017) - discrete periods of time during which the policy making process presents opportunities for conservation groups to successfully promote their agenda and solutions - is inherently based on the premise that steps forward in conservation are pushed by conservation interest groups on the authorities as they adopt policies. Michel Callon's translation theory (1986) dissects how an initially powerless innovator can (sometimes) succeed in making major stakeholders change course. Our own work on strategic environmental management analysis (2011) adapts strategic management reasoning to environmental situations where a minority actor confronts resistance to environmental change.

Practice-wise, the zelic (minority actor) paradigm is familiar to conservation operators. It is the model of an NGO mobilizing on a specific biodiversity issue and managing after a struggle to impose major changes of policy. It is the model of a grassroots movement that mobilizes against a biodiversity-damaging development project and eventually succeeds in halting that project, after obtaining support from various allies.

In this paradigm, knowledge leads to action mainly by providing resources to minority actors or alliances defending biodiversity. An ecology professor who participates in the creation of an NGO to mobilize biodiversity issues linked to his work, conservation biologists doing research with results that they know (but maybe don't say) will be instrumental as it will be used by biodiversity advocates, a committee of ecology experts that obtains an official recognition of a biodiversity issue that they know will not lead directly to government action, but will provide leverage for biodiversity activists and advocates, are some of the examples of knowledge-to-action paths in that model of action.

\section{Drop-out-and-seed: the speiric model}

Speiric reasoning shares with the stasic paradigm the diagnostic that "the system", including government policy is the cause of the problem, not the solution, but differs deeply in the formula 
for action. Instead of trying to amalgamate all those who have discontents, it relies on dispersing, i.e. on dropping out of the system individually or in small groups, and instead of confronting the system, on embarking on innovative experiments while eluding the system and offering as little hold as possible to its enforcers. The underlying theory of action for change is two steps: I can change my circumstances and biodiversity impacts individually now - provided I drop out of the system and innovate in my lifestyle - and if that works, and if other people do it successfully too, our initiatives will sow the seeds for large scale change. In the words of Guy McPherson (2011) in a vivid expression of his own drop out and seed reasoning and experience: "We make every effort to live outside the industrial economy [...]. By our example, we are demonstrating how society can be restructured so that children and other humans will understand and value the origins of food and life". Thus the choice of speiric, derived from greek verb speiroo that expresses both the act of dispersing, and the act of sowing.

How conservation science can find its place in that paradigm remains an open question. The tension here stems from the fact that science is by definition a large scale, highly institutionalized system for establishing, validating and disseminating knowledge, whereas speiric ("drop out \& seed") reasoning promotes small-scale, non-institutionalized forms of organization. Here knowledge is important, but it is expected to be independent from institutions, originated in personal experience, and (actively) exchanged in informal, non-normalized, non-institutionalized forms of validation and exchange.

9. Deeply engrained and contradictory models

\section{Table 1}

An overview of six underlying conceptual models of collective action in conservation research.

\begin{tabular}{|c|c|c|c|c|}
\hline Models & $\begin{array}{l}\text { Who is the main } \\
\text { operator of } \\
\text { conservation action? }\end{array}$ & $\begin{array}{l}\text { What does collective } \\
\text { action essentially } \\
\text { consist in? }\end{array}$ & Typical buzzwords & $\begin{array}{l}\text { Conservation research } \\
\text { is relevant if ... }\end{array}$ \\
\hline $\begin{array}{l}\text { Archic Government as } \\
\text { operator }\end{array}$ & $\begin{array}{l}\text { A government that has } \\
\text { a delegation to act for } \\
\text { the collective }\end{array}$ & $\begin{array}{l}\text { Intervention to modify } \\
\text { behaviour through } \\
\text { various tools and } \\
\text { policies }\end{array}$ & $\begin{array}{l}\text { Decision-makers, } \\
\text { Official targets, } \\
\text { legitimacy, } \\
\text { implementation, } \\
\text { policy instruments }\end{array}$ & $\begin{array}{l}\ldots \text { it provides } \\
\text { government with } \\
\text { reference goals, } \\
\text { indicators, objective } \\
\text { choice of tools }\end{array}$ \\
\hline
\end{tabular}




\begin{tabular}{|c|c|c|c|c|}
\hline Models & $\begin{array}{l}\text { Who is the main } \\
\text { operator of } \\
\text { conservation action? }\end{array}$ & $\begin{array}{l}\text { What does collective } \\
\text { action essentially } \\
\text { consist in? }\end{array}$ & Typical buzzwords & $\begin{array}{l}\text { Conservation research } \\
\text { is relevant if ... }\end{array}$ \\
\hline $\begin{array}{l}\text { Diagogic Governance } \\
\text { process }\end{array}$ & $\begin{array}{l}\text { A complex set of } \\
\text { government and } \\
\text { stakeholders }\end{array}$ & $\begin{array}{l}\text { Complex governance } \\
\text { procedures combining } \\
\text { policy and stakeholder } \\
\text { participation }\end{array}$ & $\begin{array}{l}\text { Participation, } \\
\text { participatory } \\
\text { planning, stakeholders } \\
\text { involvement, public- } \\
\text { private cooperation }\end{array}$ & $\begin{array}{l}\ldots \text { it provides } \\
\text { information to and } \\
\text { participates in } \\
\text { complex, multilevel } \\
\text { decision-making } \\
\text { processes }\end{array}$ \\
\hline Agoric Coordination & $\begin{array}{l}\text { Stakeholders } \\
\text { themselves }\end{array}$ & $\begin{array}{l}\text { Coordination and } \\
\text { direct collaboration } \\
\text { between stakeholders }\end{array}$ & $\begin{array}{l}\text { Actors around the } \\
\text { table, co-construction, } \\
\text { mediation, } \\
\text { collaboration, } \\
\text { community }\end{array}$ & $\begin{array}{l}\ldots \text { it engages all } \\
\text { stakeholders in a } \\
\text { collaborative way }\end{array}$ \\
\hline Zelic Minority actor & $\begin{array}{l}\text { A minority actor for } \\
\text { change focused on a } \\
\text { specific conservation } \\
\text { goal and acting to } \\
\text { reach it }\end{array}$ & $\begin{array}{l}\text { Strategic action to } \\
\text { obtain changes from } \\
\text { specific actors whose } \\
\text { activities impact } \\
\text { biodiversity }\end{array}$ & $\begin{array}{l}\text { Environmental } \\
\text { groups, Activism, } \\
\text { Innovators and } \\
\text { advocates. } \\
\text { Legal or political } \\
\text { challenging of } \\
\text { decisions }\end{array}$ & $\begin{array}{l}\text {... if it provides } \\
\text { compelling facts and } \\
\text { arguments to support } \\
\text { environmental } \\
\text { advocacy confronting } \\
\text { other interests }\end{array}$ \\
\hline Stasic Revolution & $\begin{array}{l}\text { Masses and their } \\
\text { leaders in opposition } \\
\text { to "the system" }\end{array}$ & $\begin{array}{l}\text { Mass action for } \\
\text { revolution i.e. } \\
\text { wholesale systemic } \\
\text { change addressing a } \\
\text { whole range of } \\
\text { societal and } \\
\text { environmental issues }\end{array}$ & $\begin{array}{l}\text { Globalization, } \\
\text { commodification } \\
\text { Capitalism, ecological } \\
\text { crisis, colonialism, } \\
\text { growth as the } \\
\text { systemic cause of } \\
\text { environmental } \\
\text { problems }\end{array}$ & $\begin{array}{l}\text {... it participates in } \\
\text { the overall efforts of } \\
\text { the vast coalition of } \\
\text { those who oppose "the } \\
\text { system" because of } \\
\text { the whole set of its } \\
\text { negative effects on } \\
\text { society and nature }\end{array}$ \\
\hline $\begin{array}{l}\text { Speiric Drop out and } \\
\text { seed }\end{array}$ & $\begin{array}{l}\text { Individual or small } \\
\text { groups who "drop } \\
\text { out" }\end{array}$ & $\begin{array}{l}\text { Drop out and seed for } \\
\text { the future through } \\
\text { radical forms of } \\
\text { autonomy and } \\
\text { informal innovation }\end{array}$ & $\begin{array}{l}\text { Alternative ways of } \\
\text { life, autonomy, } \\
\text { selfsubsistence, } \\
\text { low tech }\end{array}$ & $\begin{array}{l}\text {... it manages to adapt } \\
\text { to values of } \\
\text { informality, } \\
\text { dispersion, direct } \\
\text { experience, low tech } \\
\text { innovation }\end{array}$ \\
\hline
\end{tabular}


Table 2

The six models structure a system of crossed critiques that underlies debates on what may constitute significant action for biodiversity conservation (each box summarizes critiques from model on top of column against model on left of line).

\begin{tabular}{|c|c|c|c|c|c|c|}
\hline Model & Archic & Agoric & Diagogic & Stasic & Zelic & Speiric \\
\hline Archic & $\mathrm{x}$ & $\begin{array}{l}\text { Stakeholders } \\
\text { know better } \\
\text { than } \\
\text { government } \\
\text { what is good } \\
\text { for them and } \\
\text { for local issues }\end{array}$ & $\begin{array}{l}\text { Deficit of } \\
\text { stakeholder } \\
\text { involvement } \\
\text { makes policies } \\
\text { less relevant in } \\
\text { content, less } \\
\text { fair in process }\end{array}$ & $\begin{array}{l}\text { Authorities } \\
\text { source of the } \\
\text { problem, } \\
\text { illegitimate as } \\
\text { promoters of } \\
\text { solutions }\end{array}$ & $\begin{array}{l}\text { Authorities too } \\
\text { careful to } \\
\text { maintain } \\
\text { existing } \\
\text { balance of } \\
\text { interests, } \\
\text { detrimental } \\
\text { to biodiversity }\end{array}$ & $\begin{array}{l}\text { Authorities } \\
\text { source of the } \\
\text { problem and } \\
\text { oppose inertia } \\
\text { to innovation } \\
\text { and change }\end{array}$ \\
\hline Agoric & $\begin{array}{l}\text { Direct deals } \\
\text { raise problems } \\
\text { of legal and } \\
\text { political } \\
\text { legitimacy }\end{array}$ & $\mathrm{x}$ & $\begin{array}{l}\text { Non- } \\
\text { involvement of } \\
\text { authorities, } \\
\text { lack of } \\
\text { transparency to } \\
\text { public } \\
\text { raise } \\
\text { legitimacy and } \\
\text { effectiveness } \\
\text { issues }\end{array}$ & $\begin{array}{l}\text { Negotiation } \\
\text { between } \\
\text { established } \\
\text { stakeholders, } \\
\text { based on } \\
\text { existing power } \\
\text { balance } \\
\text { continues } \\
\text { detrimental } \\
\text { situation }\end{array}$ & $\begin{array}{l}\text { Negotiation } \\
\text { based on } \\
\text { existing power } \\
\text { balance } \\
\text { continues } \\
\text { detrimental } \\
\text { situation }\end{array}$ & $\begin{array}{l}\text { Stakeholder } \\
\text { negotiations } \\
\text { are a source of } \\
\text { inertia and } \\
\text { obstacle to } \\
\text { innovative } \\
\text { experiments }\end{array}$ \\
\hline Diagogic & $\begin{array}{l}\text { Non official } \\
\text { participants in } \\
\text { decision have } \\
\text { little } \\
\text { democratic } \\
\text { legitimacy }\end{array}$ & $\begin{array}{l}\text { Government } \\
\text { involvement } \\
\text { hinders direct, } \\
\text { autonomous } \\
\text { negotiation of } \\
\text { solutions }\end{array}$ & $\mathrm{x}$ & $\begin{array}{l}\text { Stakeholders' } \\
\text { involvement } \\
\text { alongside } \\
\text { authorities } \\
\text { favors } \\
\text { conservatism } \\
\text { or superficial } \\
\text { change and } \\
\text { hinders real } \\
\text { change }\end{array}$ & \begin{tabular}{|l} 
Input from \\
biodiversity \\
advocates risks \\
being diluted in \\
unending \\
heterogeneous \\
procedures \\
with \\
disappointing \\
results
\end{tabular} & $\begin{array}{l}\text { Cumbersome } \\
\text { and transparent } \\
\text { multipartner } \\
\text { procedures } \\
\text { tend to impair } \\
\text { autonomy and } \\
\text { informal } \\
\text { innovation }\end{array}$ \\
\hline
\end{tabular}




\begin{tabular}{|c|c|c|c|c|c|c|}
\hline Model & Archic & Agoric & Diagogic & Stasic & Zelic & Speiric \\
\hline Stasic & $\begin{array}{l}\text { Radical } \\
\text { opposition } \\
\text { lacks } \\
\text { legitimacy and } \\
\text { is sterile in } \\
\text { terms of } \\
\text { solving specific } \\
\text { problems }\end{array}$ & $\begin{array}{l}\text { Radical } \\
\text { opposition } \\
\text { disrupts the } \\
\text { quest of } \\
\text { balanced } \\
\text { solutions by } \\
\text { stakeholders }\end{array}$ & $\begin{array}{l}\text { Radical } \\
\text { opposition } \\
\text { disturbs } \\
\text { transparent and } \\
\text { legal } \\
\text { decisionmaking } \\
\text { and excludes } \\
\text { some of the } \\
\text { stakeholders }\end{array}$ & $\mathrm{x}$ & $\begin{array}{l}\text { By } \\
\text { amalgamating } \\
\text { all issues, } \\
\text { radical } \\
\text { opposition } \\
\text { risks delaying } \\
\text { or renouncing } \\
\text { the pragmatic } \\
\text { resolution of } \\
\text { specific } \\
\text { biodiversity } \\
\text { issues }\end{array}$ & $\begin{array}{l}\text { If it leads to } \\
\text { long term static } \\
\text { confrontation } \\
\text { with } \\
\text { authorities, } \\
\text { radical } \\
\text { opposition is } \\
\text { sterile and } \\
\text { hinders } \\
\text { autonomy, } \\
\text { innovation and } \\
\text { personal } \\
\text { fulfilment }\end{array}$ \\
\hline Zelic & $\begin{array}{l}\text { Special-interest } \\
\text { groups may } \\
\text { threaten } \\
\text { balance } \\
\text { amongst the } \\
\text { many public } \\
\text { interests at } \\
\text { stake }\end{array}$ & $\begin{array}{l}\text { No reason for } \\
\text { biodiversity } \\
\text { advocates to } \\
\text { claim special } \\
\text { role in } \\
\text { negotiating e.g. } \\
\text { local resource } \\
\text { use } \\
\text { arrangements }\end{array}$ & $\begin{array}{l}\text { Centering on } \\
\text { advocates of } \\
\text { one cause may } \\
\text { disrupt the } \\
\text { balance of } \\
\text { multi- } \\
\text { stakeholder } \\
\text { decision } \\
\text { making process }\end{array}$ & $\begin{array}{l}\text { Making } \\
\text { biodiversity a } \\
\text { special interest } \\
\text { cause rather } \\
\text { than part of a } \\
\text { bigger set of } \\
\text { discontents } \\
\text { hinders real, } \\
\text { deep change }\end{array}$ & $\mathrm{x}$ & $\begin{array}{l}\text { Advocacy } \\
\text { implies } \\
\text { engaging with } \\
\text { authorities: an } \\
\text { obstacle to } \\
\text { autonomy and } \\
\text { innovation }\end{array}$ \\
\hline Speiric & $\begin{array}{l}\text { Informal } \\
\text { activities raise } \\
\text { legal, fiscal, } \\
\text { social control } \\
\text { problems }\end{array}$ & $\begin{array}{l}\text { Individualistic } \\
\text { drop out } \\
\text { solutions may } \\
\text { try and escape } \\
\text { negotiation } \\
\text { with other } \\
\text { stakeholders, to } \\
\text { their detriment }\end{array}$ & $\begin{array}{l}\text { Individualistic } \\
\text { drop out } \\
\text { solutions may } \\
\text { try and escape } \\
\text { transparent, } \\
\text { deliberative } \\
\text { treatment of } \\
\text { public issues }\end{array}$ & $\begin{array}{l}\text { Dropping out } \\
\text { rather than } \\
\text { rallying to act } \\
\text { on discontent } \\
\text { weakens } \\
\text { power relations } \\
\text { for change }\end{array}$ & $\begin{array}{l}\text { Individualistic } \\
\text { solutions do } \\
\text { not contribute } \\
\text { to public } \\
\text { resolution of } \\
\text { biodiversity } \\
\text { problems and } \\
\text { may cause } \\
\text { additional } \\
\text { damage to } \\
\text { biodiversity if } \\
\text { not controlled }\end{array}$ & $\mathrm{x}$ \\
\hline
\end{tabular}


Table 1 gives an overview of the six models and how they each give a different meaning to conservation research being relevant for action. This overview can help clarify debates on bridging conservation science and action. For this, four points need to be discussed.

(1) The six paradigms of collective action are at least partly incompatible with one another. The most obvious examples are the strong oppositions between the stasic model and the archic, diagogic, zelic and speiric models, respectively on the role of existing authorities, on the fruitfulness of improving governance with existing partners, on the desirability of improving just some biodiversity issues at the possible expense of hindering a more comprehensive revolution, and on the respective merits of individual versus mass action. Less obvious examples are just as important. For instance direct negotiation between stakeholders (agoric) does mean that there has to be no or little interference from government (Ostrom, 1990) which contradicts the strong sense, in the archic paradigm of the legitimacy of authorities to supervise the resolution of public problems. As a result diagogic arrangements for governance procedures have to manage deep tensions between the two models as they try to conciliate them. Beyond these examples, such tensions can be systematized as each model has specific critiques against each of the five others. Table 2 presents this system of crossed critiques which we think is a useful contribution to analysing controversies about conservation actions, and especially discussing contrasting views about knowledge to action paths in biodiversity conservation.

(2) There is not a line of progress that would lead over time from one model to the next. All six models have coexisted in parallel for a long time in the field of conservation. Waves of fashion can bring one or another in turn to the fore of academic and public discourse. A good example is the steady rise to a quasi-hegemony (in discourse if not in practice) of the diagogic (governanceprocess) model in the 1990s and 2000s, under the pressures for integrating private interests in the funding and implementation of conservation, and for accommodating a wide array of local or traditional interest groups and concerns. Another is the rise in the current decade of the stasic (revolution) and speiric (drop out and seed) models. But beyond striking variations in their front page presence in debates - and their quite real but more moderately fluctuating influence in practice - all play an important role today, both in guiding action and in analysing knowledge-to-action problems (for a detailed example of the first five models playing out against one another over time in conservation field practice, see Mermet et al., 2013). Claims that one models comes to embrace the others or to succeed them- e.g. that stakeholder involvement and governance procedures are a progress that displaces the "old" ways of government policy and of environmentalist pressure groups - are simply one of the rhetoric devices by which proponents of each model may try to disqualify the others. 
(3) These models are not superficial framings that can be interchanged easily. On the part of the persons involved, they are most often deeply held belief and value systems, such as the (archic) sense of public service in a managing agency's staff versus the profound (stasic) indignation felt by some activists at the very thought of the compromises that such an agency makes and of the authority it exercises to the detriment of some people, contrasting again with the (zelic) relentless zeal deployed by some environmental activists as they strive to move mountains of antienvironmental inertia. In terms of theory, each of the model has deeply different roots and developments that again make it difficult to jump easily from one model to another.

(4) Finally there is no overarching model that would integrate all six perspectives - that is, there is no actionable overarching model of that sort. Indeed, it is often easy to see how different models of collective action can relate or lead to one another, as when (zelic) pressure by an NGO leads to (diagogic) prolonged debates and policy-defining procedures until (archic) authorities establish and enforce a new law. But the crucial point is not that an external observer or a historian can step back and assemble them into a wider picture, it is that in order to act, each scientist (or team of scientists) has to step forward and become an actor or associate with one or another actor, and so become situated within the wider social system and situation and adopt by necessity a partial and specific perspective on it, as they see the action system not from the outside but from within it. According to where conservation scientists happen or prefer to step into action, they will have to choose and develop a view of action and the respective roles of various actors in it that is actionable, i.e. able to guide (and to justify) their actions and that of their partners. In other words, in contrast with Watts (2017) we do not consider desirable nor possible the possibility of more integration of different social science approaches to situations through open testing on action problems, but rather that engaging in action does imply adopting a distinct perspective, and that social scientists, inasmuch as their research aims to be actionable - and thus in line with a position engaged in action have to do likewise, at the cost of the fragmentation of the theoretical landscape for which we propose an overview here.

\section{Clarifying debates on knowledge to action options}

The six models approach proposed here is a typology of the possible perspectives one can adopt about where and how to act on the social system from within it, in the name of biodiversity. This typology can help clarify debates within the conservation community on knowledge-to-action options. At the most basic level, alongside with the critique of the hatroologic model of action and other imprecise treatments of agency, it can help conservation scientists realize the importance of 
the organizational reasoning that underlies all action-related proposals, and to identify the organizational models underlying various options. Then, it can help navigate the debates, controversies and confrontations between various proposals and claims about how to overcome the knowing-doing gap and create useful connexions. Clashes between promoters of different options can be examined in a colder spirit once they are situated in the system of crossed critiques between the six models.

For instance when looking at the diversity of reactions of groups with different political or analytical orientations as they consider the possibility of systemic collapse of our economic model and its ecological basis (see for instance Pollard, 2014; Servigne and Stevens, 2015), one can see how they map out on the models of collective action. An archic reaction may be for authorities to claim control, or act to organize control of the situation (and for citizens to demand control); an agoric response may be to promote a return to community organization; for a stasic analyst or militant, collapse will be viewed as an ally and welcome opportunity in overthrowing the system; a zelic response might be concern that painfully acquired conservation guarantees (e.g. protected areas) might be wiped away in the turmoil, while a speiric-oriented person will advance the unstoppable advance of collapse as the perfect justification for going off-grid to dodge the catastrophy while making sure the seeds for a new world are in place when the old one will have ceased to function. And what about the diagogic model, one may ask? Well, as it requires everyone to agree on the issue and the solutions... it may hardly be able to consider seriously and in time the possibility of collapse.

Positions in such debates (one may think also of the debate on evidence-based conservation, on community-based conservation, on biodiversity offsets and many others) can be broken down between on the one hand controversies of principle between premises, perspectives, schools of thought or general political positions, and on the other hand different tangible and specific aspects of actual field situations, of conservation problems that one is considering before taking action. The first bring only very generic information to the table, and information on the general beliefs and affiliations of the authors. The second reflect the complexity of actual conservation situations on the ground. An acid test to tell them apart could consist in asking systematically three questions. What is the underlying paradigm of organized action in this analysis or proposal? What part of the analysis or proposal would have resulted from the premises regardless of field investigation, and what part is rooted in case-specific field investigation? To what extent do the (implicit or explicit) proposed actions pragmatically promise tangible positive biodiversity outcomes versus other outcomes (political, social, economic, etc.) that may be of concern to the authors of the analysis or proposal? 
As the conservation science community continues its mobilization, its strategic reflections and its soul-searching on knowledge-to-action paths, it becomes increasingly clear that several very different and even contradictory models of action will continue to coexist and develop in parallel. A clearer perception of underlying models of organised action will help put in perspective recurrent clashes based on premises and principles, and focus on deepening what each perspective can bring in terms of practical and context-relevant understanding, depending on the particulars of each biodiversity field situation and context for action. It is important to realise that work based on each of the models has both some potential to help conservation scientists find relevant paths for action and some serious limitations; both are best explored in reflexive action, confronting actual biodiversity issues.

\section{References}

Callon, M., 1986. Éléments pour une sociologie de la traduction - la domestication des coquilles Saint-Jacques et des marins pêcheurs dans la baie de Saint-Brieuc. L'Année Sociologique 36, 169201.

Carson, R., 1962. Silent Spring. Houghton Mifflin, Boston.

Certain, R., 2015. Vigneux-de-Bretagne: des biologists agressés sur la ZAD. Presse Océan 30 (April) 2015.

Cook, C.N., Mascia, M.B., Schwartz, M.W., Possignham, H.P., Fuller, R.A., 2012. Achieving conservation science that bridges the knowledge-action boundary. Conserv. Biol. 27 (4), 669678.

Deleuze, G., Guattari, F., 1980. Mille Plateaux. Editions de Minuit, Paris.

Hamilton, C., 2017a. The great climate silence: we are on the edge of the abyss, but we ignore it. The Guardian (May 5th), 2017.

Hamilton, C., 2017b. Defiant Earth: the Fate of Humans in the Anthropocene. Polity Press, Cambridge U.K.

Knight, A.T., Cowling, R.M., Rouget, M., Balmford, A., Lombard, A.T., Campbell, B.M., 2008. Knowing but not doing: selecting priority conservation areas and the research- implementation gap. Conserv. Biol. 22, 610-617.

Kovel, J., 2002. The Enemy of Nature: The End of Capitalism or the End of the World? Zed Books, London.

McPherson, G., 2011. Going back to the land in the age of entitlement. Conserv. Biol. 25 ( ${ }^{\circ} 5$ ), $855-857$. 
Mermet, L., Billé, R., Leroy, M., 2010. Concern-focused evaluation for ambiguous and conflicting policies : an approach from the environmental field. Am. J. Eval. 31, 180-198.

Mermet, L., Homewood, K., Dodson, A., Billé, R., 2013. Five paradigms of collective action underlying the human dimension of conservation. In: McDonald, D., Willis, K. (Eds.), Key Topics in Conservation Biology. Wiley-Blackwell, Oxford, pp. 42-58.

Mermet, L., 2014a. Les paradigmes contradictoires de l'action organisée en matière de biodiversité. In: Gauthier-Clerc, M., Mesleard, F., Blondel, J. (Eds.), Sciences de la Conservation. De Boeck Supérieur, Louvain-la-Neuve, pp. 215-221.

Mermet, L., Laurans, Y., Leménager, T., 2014b. Tools for What Trade? Analysing the Utilisation of Economic Instruments and Valuations in Biodiversity Management. AFD, collection A Savoir, Paris, pp. 344 p. n²5.

Mermet, L., Leménager, T. (Eds.), 2015. Development and Biodiversity: Navigating the Environmental Turning Point. AFD, Recherches, Paris 342 p.

Ostrom, E., 1990. Governing the Commons: The Evolution of Institutions for Collective Action. Cambridge University Press, Cambridge.

Palmer, M., 2012. Socioenvironmental sustainability and actionable science. BioScience, 62 (1), $5-6$.

Pollard, D., 2014. Preparing for Collapse. ; Accessed March $23 \quad 2018$. https://ukiahcommunityblog.wordpress.com/2014/06/16/preparing-for-collapse/.

Rose, D.C., Mukherjee, N., Simmons, B.I., Tew, E.R., Robertson, R.J., Vadrot, A.B.M., Doubleday, R., Sutherland, W., 2017. Policy windows for the environment: tips for improving the uptake of scientific knowledge. Environ. Sci. Policy. http://dx.doi.org/10.1016/j.envsci.2017.07.013. Sabatier, P.A., Jenkins-Smith, H.C. (Eds.), 1993. Policy Change and Learning - An Advocacy Coalition Approach. Westview Press, Boulder, CO.

Sandbrook, C., 2017. Weak yet strong: the uneven power relations of conservation. Oryx 51 (3), 379-380 2017.

Servigne, P., Stevens, R., 2015. Comment tout peut s'effondrer. Petit manuel de col- lapsologie à l'usage des générations présentes. Seuil, Paris.

Toomey, A.H., Knight, A.T., Barlow, J., 2016. Navigating the space between research and implementation in conservation. Conserv. Lett. 2016 (October), 1-7. http://dx.doi. org/10.1111/conl.12315.

Watts, D.J., 2017. Should social science be more solution-oriented? Nat. Hum. Behav. 2017 (1), 0015. 
Wunder, S., 2005. Payments for Environmental Services: Some Nuts and Bolts. Occasional Papers. Center for International Forestry Research, Indonesia. 